\title{
Medievalista
}

Online

$30 \mid 2021$

Número 30

from the conceptualization to the articulation of ceremonial

(10th-11th centuries)Doctoral thesis in History presented at the

University of Lisbon in 15th July, 2020. Supervised by Professor

Hermenegildo Fernandes and Professor Hugh Kennedy

The door of the caliph in the Umayyad al-Andalus

from the conceptualization to the articulation of ceremonial (10th-11th centuries). Doctoral thesis in History presented at the University of Lisbon in 15th July, 2020. Supervised by Professor Hermenegildo Fernandes and Professor Hugh Kennedy

\section{Elsa Cardoso}

\section{(2) OpenEdition}

\section{Journals}

Electronic version

URL: https://journals.openedition.org/medievalista/4575

DOI: 10.4000/medievalista.4575

ISSN: 1646-740X

\section{Publisher}

Instituto de Estudos Medievais - FCSH-UNL

Electronic reference

Elsa Cardoso, "The door of the caliph in the Umayyad al-Andalus", Medievalista [Online], 30 | 2021,

Online since 01 July 2021, connection on 28 July 2021. URL: http://journals.openedition.org/ medievalista/4575; DOI: https://doi.org/10.4000/medievalista.4575

This text was automatically generated on 28 July 2021.

Mediavalista está licenciado com uma Licença Creative Commons - Atribuição-NãoComercial 4.0 Internacional. 
from the conceptualization to the articulation of ceremonial (10th-11th centuries)Doctoral thesis in History presented at the University of Lisbon in 15th July, 2020. Supervised by Professor Hermenegildo Fernandes and Professor Hugh Kennedy The door of the caliph in the Umayyad al-Andalus

from the conceptualization to the articulation of ceremonial (10th-11th centuries). Doctoral thesis in History presented at the University of Lisbon in 15th July, 2020. Supervised by Professor Hermenegildo Fernandes and Professor Hugh Kennedy

\section{Elsa Cardoso}

\section{EDITOR'S NOTE}

Data recepção do artigo / Received for publication: 28 de Fevereiro de 2020

\section{AUTHOR'S NOTE}

This thesis was funded by the Portuguese public agency for science Fundação para a Ciência e Tecnologia (FCT), with a Ph.D. grant (ref.: PD/BD/113904/2015), under the doctoral program PIUDHist - Programa Inter-universitário de Doutoramento em História.

I would like to thank Prof. Dr. Sabine Panzram, director of the RomanIslam - Center for Comparative Empire and Transcultural Studies (Universität Hamburg), whose support made possible the completion and defense of my Ph.D.

1 The main purpose of the dissertation is the conceptualization of the court, palace and ruler of the Umayyad Caliphate of al-Andalus (929-1031). The Western terminology still plays a normative role in the representation of foreign courts, determining concepts that 
fit poorly into chronologies and traditions with their own dynamics, hierarchies and specificities, which is the case of the Muslim courts. Far from being the paradigm of court society, the Western court model consists of a case amongst many. Not complying with the Western model and terminology does not mean we are not before a real court society, as in fact the medieval Muslim court model testifies. Such model is discussed in the light of a courtly common language to the Mediterranean and Eastern societies of the tenth and eleventh centuries.

2 The strong conceptualization of the Umayyad court of Cordoba was further highlighted through the articulation of the ceremonial, as the mise-en-scène of such conceptualization and legitimacy, expressed by gestures, caliphal insignia and hierarchies, which was understood by the Mediterranean and Eastern paradigm of court and ceremonial. Thus, both the conceptualization and the articulation of the ceremonial of Cordoba are discussed, through the comprehensive survey of primary Andalusi sources. The dissertation further considers a preliminary comparative approach, developed on examples contained in selected primary sources, but mainly through the resort to secondary literature on the Umayyad Caliphate of Damascus, the 'Abbasid and Fatimid Caliphates, and the Byzantine Empire.

Sources elaborate a specific terminology for the medieval Muslim court societies and, in the specific case of the Umayyad Caliphate of al-Andalus, the research carried out for the dissertation established that the court is usually enunciated as Bāb Suddat al-Khalifa ("The door of the Sudda of the caliph") - a reference to the symbology associated to the main city gate of Cordoba - or simply as Bāb. Bāb Suddat al-Khalifa appears to be the most emblematic concept to name the Umayyad palace, its society, the access and submission towards the caliph, which is additionally interpreted in the thesis in the framework of the performance of ceremonial, the language and terminology used in such ceremonies, as well as within the Byzantine and Persian traditions, that overrun the concepts idealized for Western court societies.

4 Thus, the study of the Umayyad caliphal court of al-Andalus, the analysis of its concepts and symbology, as well as the articulation of its ceremonial are the subject of the dissertation. The tenth century unlocks a privileged era for the articulation of the Umayyad ceremonial and court ritual within the political framework of the Mediterranean. Cordoba institutionalizes a ritualized ceremonial as a result of the political strength of the dynasty, but also as a way to display a theatre of power. Such articulation cannot be explained without geographical and chronological contextualization. Chronologically, this research covers the period of the sovereignties of the first Umayyad caliph of al-Andalus, 'Abd al-Rahmmān III (r. 912-961), and of his son and heir, al-Hakam II (r. 961-976). The choice of such chronology is not by chance. 'Abd al-Rahmān III's rise to power marks the institutionalization of the court and of a standardized ceremonial which coincides with the declaration of the Umayyad Caliphate of al-Andalus in 929. As noted by Miquel Barceló, ceremonial developed around the "evanescent caliph" was not the result of a mere ideological requirement, but rather the requirement was the result of a strong political power based on the thorough collection of taxes, which gave rise to a wide state bureaucracy, allowing the caliph to become an unattainable and invisible figure, though symbolically present at all times in his palace-city complex ${ }^{1}$. The information recorded on rituals under the rule of al-Hakam II allows not only the development of the research on court studies and ceremonial, as it also evidences a strong complexification of ceremonies and ritual, 
in comparison with the rule of 'Abd al-Rahmān III. The death of al-Hakam II marked the end of a stable de facto power of the Umayyad caliphs of al-Andalus. His son and heir Hishām II (r. 976-1009, 1010-1013) ascended to the throne when he was only eleven years old, becoming a puppet caliph under the de facto rule of the 'Amirid dynasty, first under the tutelage of the hājib (chamberlain) Muhammad b. Abī 'Āmir al-Manșūr (d. 1002), and then of his sons 'Abd al-Malik al-Muzaffar (r. 1002-1008) and 'Abd al-Rahmān Nāșir al-Dawla al-Ma'mūn (r. 1009-1009), better known as Sanchuelo, as his mother, 'Abda or Urraca, was the daughter of Sancho Garcés II of Pamplona (r. 970-994). After Sanchuelo made Hishām II name him his heir and successor of the caliphate in alAndalus, such pretension of dismissing the Umayyad lineage triggered not only the assassination of the hajjib in 1009, as well as gave place to a troubled period which saw the succession of several Umayyad suitors for the seat of the caliphate, thus finally culminating in the end of the Umayyad power of al-Andalus in 1031 and the beginning

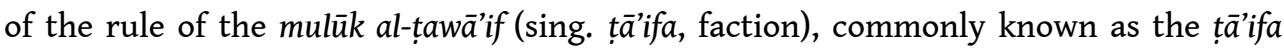
kingdoms. Thus, taking in mind the sources available and the historical and political context, the dissertation focuses on the sovereignties of both the first and the second caliphs of Cordoba, resorting however to other examples of rituals, ceremonies and insignia of the Umayyad 'Amirate and the 'Amirid period.

Being the court the central core of the thesis, first the research aims at studying the conceptualization of the Umayyad Andalusi caliphal court and its caliph. How do the sources name and define the concept of court and ruler? How were these concepts described and understood by the Umayyad Caliphate of al-Andalus? To which situations were these concepts associated to? What was the meaning and symbology of such concepts? As stated before, for interpreting and analysing such concepts, I resorted in some cases to a preliminary comparative approach, with other court models: the Umayyad Caliphate of Damascus, the 'Abbasid and Fatimid Caliphates and the Byzantine Empire. While Court Studies is a well-developed field, especially for the modern period, that is not the case for the study of Muslim medieval courts, for which case even the concept of court (or medieval) is not applicable. Albrecht Fuess and JanPeter Hartung have pointed out that after the work of Norbert Elias ${ }^{2}$ on Louis XIV's court, which triggered a constant academic production on European court societies, several questions still remain to be answered. As for Muslim court societies the problem is more serious, according to the same authors, since the existing fragmentary case studies prevail on a "basic research", a situation they believe demands comparative perspectives "which recognize the specificity of the Muslim context" 3 . For Nadia Maria El Cheikh, "the court was roused from its historiographical somnolence mostly through the efforts of Norbert Elias whose "epoch-making studies restored the relevance and legitimacy of the court as a theme of research". However, she also alerts to the "problem of definition," related to the specificities of each case study, which for her explains partially the almost inexistence of court studies for some Islamic chronologies ${ }^{4}$. Thus, the fundamental work of Elias is partially responsible for the association of the French model to a court society prototype, producing an archetypal imaginary around the concept of "roi soleil," which resulted furthermore from the proliferation of studies on European courts and the perception of the seventeenth century French court society as its paradigm. Although it was not the intention of Elias to demonstrate that the French court was the ultimate and the first court to be developed into an actual society, the result was that its approach - as the court was for the first time thought as a society - turned instead the French court society as 
unmatched in the eyes of the public. This is the starting point of the dissertation, as it is discussed in the chapter concerning the concepts. Despite the problems of definition - as pointed out by El Cheikh when addressing the 'Abbasid court and courtiers ${ }^{5}$ - and for practical purposes, the word court is used throughout the dissertation, however in italic, as we are facing a Latin terminology, bearing thus a specific Western conceptualization.

Secondly, the dissertation aims at understanding the development and articulation of ritual and ceremonial language of the court. How were the ceremonies and rituals performed and understood? To whom were they addressed and what was their meaning? For this purpose, the second part of the dissertation is dedicated to the analysis of a selected set of Umayyad Andalusi ceremonies, addressed in a comparative perspective. Keeping in mind that the subject of this research is the Umayyad Caliphate of al-Andalus, and due to the imposing time constraints of the research, the comparative approach must be understood as introductory of a research on comparative Islamic medieval Court Studies which will be developed during the postdoctoral phase ${ }^{6}$.

The dissertation is composed by two parts. The first part comprises the introduction to the sources used for this research and the state of the art, discussing the approach on court, ritual and ceremonial of the works concerning such issues, for the time and space framework elected. Regarding the typology of the sources, the codification of court and ceremonial underwent during this time is witnessed by tenth and eleventh centuries historians who wrote manuals on rules of attendance, such as the Byzantine Book of Ceremonies of Emperor Constantine VII (905-959), the 'Abbasid Rules of the House of the Caliphate by Hilāl al-Sābī' (969-1056) or the Fatimid Book of Etiquette necessary for the followers of the Imam by Qādī al-Nu'mān (d. 974) ${ }^{7}$. Although a similar manual is unknown for the Umayyad Caliphate, descriptions of ceremonies kept mainly on Arabic historical accounts with narrative and compilation features, in the form of akhbār (sing. khabar, news, report), are likely to be analysed for the reconstruction of such ceremonial and protocol models. That is the case of the main source for the history of the Western Umayyad Caliphate, the surviving fragments of the Kitäb al-Muqtabis fi ta'rikh rijāl alAndalus, by Ibn Ḥayyān al-Qurțūbī (987-1076), which are compiled through pre-existent sources, especially the Akhbār mulūk al-Andalus by Aḥmad b. Muḥammad al-Rāzī (d. 955) and his son 'Isā b. Ahmad al-Rāzī (m. 980), historians of the Umayyad court'.

8 The quorum of the first part concerns the conceptualization of the court of the Umayyads of Cordoba. An introductory part of the chapter of the concepts aims at discussing the general interpretations on the court, adopting an essayistic and critical approach on the contemporary Western views of the court, and especially the oriental court, allowing for that purpose examples on art, music and literature, relevant to discuss the change in time of the concept of court. Assuming such changes and prejudices pertaining to the court, and especially the oriental court, this introductory subchapter is followed by another which stances the definition of the court in historiographical studies addressing the Muslim courts as well as the fundamental studies which allowed the development of this research and served as a methodological approach for this dissertation.

9 The chapter is then divided into three main parts, which have been the result of the survey of sources concerning the Umayyad Caliphate of al-Andalus. The first, under the title "The Umayyad Caliph: a Sun-Caliph?" is the product of the conceptualization of 
the caliphal court of Cordoba centralized in the figure of the caliph, evoking astronomical metaphors to refer to the sovereign, especially in the panegyric poetry transmitted in historical compilation sources. Furthermore, being the ceremonial, together with the court, the main theme of the dissertation, it was always the figure of the caliph who was the centre of the performance of ceremonial, even when he was not present, displaying for that purpose insignia which remitted to the image of the ruler. As mentioned above, the development of the field of Court Studies for Western societies has contributed to the general association of the court with a European court model, especially defining Versailles as a prototype. This is not saying that Court Studies developed for Western societies created such image, but rather that the prolifically production on such court societies resulted in the general (and sometimes even academic) imagery around the French court society and its ruler. However, the imagery paved around Louis XIV as the "roi-soleil" was certainly not an original idea, which was already a reality for Ancient societies, a metaphor inherited by the Islamic Empire after the conquests. For instance, the Umayyad caliph of al-Andalus was described as a "rising sun" (shams $\left.{ }^{a n} t \operatorname{ta}^{2} i^{\prime}{ }^{a} t^{a n}\right)^{9}$, as well as "a sun of the caliphate" (shams khiläfat ${ }^{i n}$ ) in panegyric poetry. ${ }^{10}$ According to the poem, the dynastic legitimacy was granted to the Umayyads of Cordoba in the West and in the East, as they were the inheritors of the true caliphate, through their ancestors, the Umayyad caliphs of Damascus. The poet further mentions in his verses that this "rising sun" would shine in the "two Easts" (almashriqayn), as well as Syria (al-Shām) would rise again to receive the long overdue caliph. As pointed out by Vallejo, the symbology of the two Easts was recalled in the architecture of the palace-city of Madinnat al-Zahrā', where the Majlis al-Sharqi (Eastern Hall) and the Majlis al-Gharbi (Western Hall) - facing each other - retained the Umayyad claims both in the East and West, a theatralization staged when both the caliph and the heir received simultaneously, each on his majlis ${ }^{11}$.

10 From the adoption of such terminology to refer to the ruler, this subchapter further addresses the official titles and other epithets of the Umayyad caliph, such as khalifa and amir al-mu'minin, imām ${ }^{12}$ or mahdi $\bar{\imath}^{13}$, occurring in letters transmitted by narrative sources or in poetry contained in historical accounts. We should not forget that far from being merely an art form with little official applicability, the panegyric poetry was not only an authentic Arabic institution, as it was moreover part of a court ceremonial setting, reflecting thus its official status. While the main title to refer to the Umayyad caliph in the official correspondence, especially with the governors of alAndalus and the North African tributaries, was amir al-mu'minin $n^{14}$, the appellation of khali $\mathrm{fa}^{15}$ appears to be the most common to refer to the caliph when he is mentioned in the accounts, and especially in the Muqtabis of Ibn Hayyān. Keeping in mind the discussion triggered by the work of Crone and Hinds, the examples shown in the accounts for the Umayyad al-Andalus, as in the East, the title khalif $a^{16}$ appears to stand for khalīfat Allāh and not khalīfat rasūl Alläh. While the concept khalīfat rasūl Allāh appears to be inexistent in sources accounting the Umayyad al-Andalus, khalifat Allāh does appear in Ibn Ḥayyān's Muqtabis. When one day 'Abd al-Raḥmān III decided to spend the night with his wife and cousin Fāțima al-Qurayshiyya, Marjān, a concubine of the ruler, congratulated her for such an honour bestowed on her by the khalifat Alläh, as she would be able to spend the night with the sayyid al-barriyya (the lord of the universe), in a reference with further eschatological meaning ${ }^{17}$.

The concept sultān is also discussed in this subchapter. Eduardo Manzano has underlined that the term sultān was not used as a title until the eleventh century, but 
rather as a reference to the central power, embodied by the caliph, but which surpassed him, such as 'askar al-sulțān (army of the sulțān) or rasūl al-sulțān (envoy of the sultān $)^{18}$. However, in some of the references in Ibn Hayyān, it appears to be already used as a title and not only a reference to the central power. Perhaps the most evident case is the account of the desertion of the battlefield after the defeat of Simancas in 939, where the caliph - referred to as al-sultān - is said to have entered the pit (alkhandaq) dug by the Christian army as a trap ${ }^{19}$, which might mean that as early as the tenth century, the concept was becoming a title.

The second subchapter discussing the Umayyad terminology is the central part of the conceptualization, under the title "Bāb Suddat al-Khalifa or the court of the caliph: an Umayyad Sublime Porte?", which the doctoral research has shown as the most iconic term to refer to the Umayyad court of Cordoba. For example, in March 938, 'Abd alRaḥmān III received Muḥammad b. Hāshim al-Tujībī, the governor of Zaragoza, at his capital ${ }^{20}$. According to the account, Muhammad al-Tujībī went to "Bāb Suddat alKhalifa" ${ }^{21}$. Bāb al-Sudda was the most important door of Cordoba, as Ibn Ḥayyān even states it himself when accounting the crucifixion and execution of Furtūn b. Muhammad in the aftermath of the military defeat of Simancas in $939^{22}$. There is a clear perception of $B \bar{a} b$ as the ultimate illustration to the entrance towards the caliphal presence, who embodies the representation of the precinct of the palace and the caliphal administration and bureaucracy, in short what the Western historiography depicts and describes as the court. Bāb Suddat al-Khalifa referred thus to the palace, the entourage of the caliph, and the submission towards the ruler, in short, to what we nowadays unjustly understand as the court of the caliph.

The terminology was comprehensively surveyed in sources accounting the Umayyad caliphates of 'Abd al-Rahmān III and al-Hakam II, and the references and examples shown in the subchapter underline the understanding of such terminology which remits, once more to the figure of the caliph, as well as his power, insignia, justice and punishment. The use of the reference of the door as a metaphorical and abstract idea of the palace and the court was surely not unknown to Ancient societies, however the term became popularized in the West through the European accounts on the Ottoman $B \bar{a} b$ al-'Âli, which was the representation of the court of the sultan, and became known in the West as the Sublime Porte.

Furthermore, this subchapter addresses the symbology of the gate or the door in a comparative perspective with previous traditions, also attending to the architecture of the caliphal courts, through the archaeological interpretations of the historiography and art history. Moreover, the door is analysed as the public representation of the caliph, as well as the stage for submission, punishing traitors and other sentenced by their faults, usually associated to the breaking of the oath of allegiance. In his thorough study on the meaning and uses of the Sudda, Leopoldo Torres Balbás had already noticed the punitive symbology attributed to the door, as it was the stage for the exhibition of the convicted ${ }^{23}$. The work of Omayra Herrero on the forgiveness of the sovereign and the places of punishment in al-Andalus had also drawn the attention to the remarks made by historiography on the similarities of the symbolic designation of the Bāb al-Sudda of Cordoba with other Medieval and Modern gates and palatinecomplexes, further linking the symbolic designation of Bāb al-Sudda to the palace and power with its use as the epitome of the exhibition of power, submission and punishment ${ }^{24}$. Pedro Chalmeta had already pointed out that the Bāb al-Sudda of Cordoba 
was the medieval corresponding of the Ottoman Bāb al-'Āli or Sublime Porte, as well as a designation common to several cultures of the Antiquity and Medieval times ${ }^{25}$. LéviProvençal, when describing the gates of the city of Cordoba, suggests that the word Sudda came to name, according to him in "Hispanic-Arabic", "the "court' of the sovereign" ${ }^{26}$. However, despite these suggestions on the association of the Bāb al-Sudda with the symbolic representation of the court, further proof and a thorough survey on sources was much needed, as well as an analysis of the representation of the court as the Bāb al-Sudda, and the representation of the gate itself as the embodiment of such concept and depiction.

The $B \bar{a} b$ emerges thus as an omnipresent concept in order to perceive, conceive and imagine the court of the Umayyad Caliphate of al-Andalus. The Bäb Suddat al-Khalifa further contains in itself a triple symbology of the Umayyads of Cordoba. Being the gate of submission and punishment stressed its understanding as the maximum representation of power. Its definition as the spatiality of the qașr remits for the abstract meaning of the court. Moreover, being the access to the palace underlined the $B \bar{a} b$ as the ultimate representation of the inaccessible figure of the caliph, the Bāb alKhalifa, the Umayyad Sublime Porte. The Sudda, while representing this inaccessible ruler, and the passage to attain it, also remitted to the main architectural spaces of the palace-city: the Dār al-Khalifa, or the residence of the caliph, and the majlis, where the ruler received. Nevertheless, while the Dār al-Khalifa or the majlis were inaccessible to most of the caliphal subjects, the Bāb Suddat al-Khalifa could be seen and could be transposed by the common subjects of the Cordoban caliph, thus being not only the epitome, but also the most popular representation of the caliphal power. The resort to the symbology of the door and the gate in the ceremonial language of the caliphates and empires is frequently accounted in sources. Perhaps one of the most iconic accounts for the "Abbasid Caliphate is the reception of Byzantine ambassadors, in 917, in Baghdad, by the Caliph al-Muqtadir. According to the descriptions preserved by alKhațīb al-Baghdādī, Hilāl al-Ṣābī' and Miskawayh, the ambassadors first were led to an ad aeternum succession of passages, hallways, palaces and courts inside the 'Abbasid palace-city. Every time they entered a new palace or court, they were led to think that finally they would enter the presence of the Caliph al-Muqtadir, as happened twice with the Byzantine envoys, first when they entered the residence of the hājib Nașr alQushūrī, and then the residence of the wuzară', according to al-șābi ${ }^{-27}$. Miskawayh also underlines the endless route undertaken by the envoys, who were led by the hujjäb through never-ending passageways and terraces ${ }^{28}$. El Cheikh had already pointed out the labyrinthine ideal of the forbidden palace represented by this endless waiting and route, which was intended to cause anxiety, inside the secret passages of the palace, for the longing of the figure of the caliph ${ }^{29}$. This forwards us to nothing less than to the idea transmitted by Clifford Geertz's model of the nineteenth century negara state of Bali, in which the palace is described as a succession of "courts within courts," underlining the symbology of the palace as the divine $\operatorname{cosmos}^{30}$.

The symbology of the gate was also present in the "Abbasid court of Baghdad, as even the palace was named "the Golden Gate" ${ }^{31}$ or "the Green Dome" (a reference to the throne room) ${ }^{32}$, thus entangling the meaning of the door to the representation of power. Both the Sudda of Cordoba and the Sudda of Madinat al-Zahrā' had a majlis on the rooftop, also a characteristic shared by Baghdad, Cairo and the Eastern Umayyad palaces. This majlis was not a throne room, nevertheless, as a place where the kursi (chair) of the șāhib al-madina was, in both cases of Cordoba and Madinnat al-Zahrā', ${ }^{33}$ or 
where the ruler left his son as his representative when leaving in military campaign, in the specific case of Cordoba ${ }^{34}$, the Sudda represented the epitome of power, as well as projected the inaccessible figure of the caliph, sat on his throne room or majlis. Furthermore, in sources, $B \bar{a} b^{35}$ - a short concept resulting from the changes and shaping of the original concept of Bāb Suddat al-Khalifa - turned to be an allencompassing abstract term unravelling the medieval Christian court viewed by the Umayyad eye: even the court of a Christian "tyrant" and tributary such as Ramiro II of León is described as the $B \bar{a} b^{36}$.

17 The third conceptual topic of the chapter on concepts concerns the spatial understanding of the court: the palace of the caliphate or the Qașr al-Khila $f a$. The subchapter titled "Qașr al-Khiläfa: space and society" discusses if such terminology addressed only the spatiality of the palace, or if it rather suggested a broader concept intending to designate the entourage and the administration of the Umayyad sovereign of al-Andalus, further resorting to a comparative approach, especially with the "Abbasid court. While Bāb Suddat al-Khalifa, Bāb al-Sulțān or Bābi-hi ("his door," the caliph's) were meant at underlining the symbology of the submission to the caliph and the abstract idea of his court and entourage, the Qașr al-Khiläfa was more often associated to the location and the architecture of the palace. Nevertheless, I have pointed out that Qașr al-Khilāfa had, on some occasions, clear symbolic features, especially in the panegyric poetry. This is evident when the poet mentions the "House of the Caliphate," in relation to the account where the prince Hishām, titled as the badr al-mulk - "the moon of power" - is said to live at the Qașr al-Khiläfa ${ }^{37}$. The reference to the qașr as an appellation to the court is also evident when al-Maqqari accounts the oath of allegiance to al-Hakam II by the courtiers: bay'a ahl al-qașr ("oath of allegiance of the people of the palace," literally $)^{38}$. Thus, if it is true that the Umayyads of Cordoba created a specific terminology for each concept, it is also manifest that sometimes there was an overlapping of such conceptualization, thus entangling the different layers of the perception of the court and the caliphal entourage.

Thus, the chapter concerning the conceptualization of the Umayyad court of al-Andalus aimed at demonstrating that far from conceiving the Western court model as the paradigm, or as the maximum achievement of a developed court, the caliphal courts were in fact complex court societies, creating their own concepts and terminology, which was part of a common ceremonial, ritual and insignia language, shared by several caliphal and Muslim powers, but also inherited from previous empires and understood by other Christian and imperial powers.

The second part of the dissertation is dedicated to the articulation of ceremonial, under the title "A ceremonial common language in the Mediterranean: rituals of court in a comparative perspective". The articulation of ceremonial was nothing less than the mise-en-scène of the conceptualization of the court, the caliph, the hierarchy of the court and the administration. As underlined before, this second part must be understood as a preliminary study concerning the performance of ceremonial, in a comparative perspective, within the Mediterranean.

The selection of ceremonial situations was made according to the most relevant information available in sources concerning the Umayyad Caliphate of al-Andalus. One of the themes addressed in this chapter is the bay $a$ ritual, ${ }^{39}$ where both ceremonies of the oath of allegiance to "Abd al-Rahmān III ${ }^{40}$ and al-Hakam II ${ }^{41}$ are discussed in the whole context of the Umayyad court ritual. Furthermore, the comparative perspective 
also allows us to understand how important the hierarchy and the distinguishable sovereignty insignia were. The most distinguishable sovereignty insignia between Christian and Islamic courts is perhaps the wearing of the tāj (crown), which is why the consideration of its usage has as a starting point the analysis of the imperial ceremony of the crowning of the Byzantine emperor ${ }^{42}$. Nevertheless, its use is also attested for the caliphates, even though with distinct features from the Christian crowns, while at the same time remaining associated to a foreign insignia of power.

Another part of the chapter is dedicated to the study of different types of ceremonies, between the palace and public rituals. The religious festivities, for which the caliph would hold a palace reception, at the main hall of receptions of the palace-city of Madinat al-Zahrā', the Majlis al-Sharqi, or the Eastern Hall, consist of the best documented palace ceremonies. For the tenth century such descriptions are perhaps the main sources for understanding the organization and hierarchy of the caliphal court of Cordoba, as a great part of the accounts are dedicated to the organization of classes or order of precedence (marātib, tartib) inside the majlis, aimed at insistently underlining the hierarchy within the court. Furthermore, this is an intrinsic characteristic of a non-processional ceremonial, as the Umayyad ceremonial is often considered. Although it is undeniable that the Umayyad ceremonial was much more of what I have referred to as an audience ceremonial than a processional one - such as in the Fatimid case, where the caliph was paraded through the city, one of the most important features in $\mathrm{Cairo}^{43}$-, the sovereignty of al-Hakam II shows us how important the ritualization of the military parades or the horse ridings of the caliph were in Cordoba. Furthermore, the public ritualization was already evident under the rulership of the first caliph of Cordoba, especially with what we may call a liturgy of blood, developed around the theatralization of the death penalty, a typology which is also highlighted in the chapter concerning ceremonial. The most evident case of a carefully ritualized liturgy of blood was staged in the aftermath of the disastrous defeat of Simancas, in August 939, against a Christian joint force led by King Ramiro II of León. 'Abd al-Raḥmān III accused one of his military officials, Furtūn b. Muhammad, of betraying the caliphal army together with ten officials, who had presumably left the battlefield after the Muslim forces were led by the Christian army to a pit (al-khandaq, which became known as the name of the battle), where they died of the fall or crushed. Before the arrival of the caliph to Cordoba, Furtūn had already been crucified and was killed when 'Abd al-Rahmān III arrived at the Bāb al-Sudda. Not long after, ten crosses were raised at the attic located on the right-hand side of the Bāb al-Sudda, built especially for that purpose, and the ten traitors were crucified alive while the caliph, in an unprecedented act, addressed the Cordoba population who had gathered, terrified, to attend the scene $e^{44}$. Furthermore, the chapter on ceremonial articulation dialogues frequently with the chapter dedicated to the concepts. For example, in the case of the punishment to the presumable traitors of Simancas, the double meaning of the Bāb alSudda (submission and punishment), becomes consolidated into the absolute power of the caliph, who was the representative of the palace, whose symbology was embodied by the Bāb al-Sudda.

These three types of ceremonials, which I have designated as audience ceremonial, public ceremonial and blood ceremonial - could not be more entangled as in the mise-en-scène of the death penalty of one hundred Christian prisoners, who had been captured after attempting a failed incursion into Muslim territory, in the munya of al-Nā'ūra, where the caliph seating on the upper majlis, could see and could be seen by the Cordoban 
population who had gathered there to witness his justice ${ }^{45}$. On March 2, 939, preceding the military campaign of Simancas, the caliph sat on the upper majlis of the munya, which faced the river, where he presided over the ritual execution of the barbarians ('ilj). According to the account, the ceremony took place after the Friday prayer, in order to be witnessed by the caliphal subjects, who attended it under the watchful sight of the caliph.

On the one hand, if the audience ceremonial clearly develops under the rule of al-Hakam II, on the other, the accounts on the public appearances of the caliph, military parades and processions also reveal the complexification of the public ceremonial. Inasmuch as the caliph remained an inaccessible and secluded ruler - which was in itself a ceremonial feature - when he left his palace for public appearances, either at the Sudda or in a ruküb (horse riding), such appearances were carefully planned and ritualized. If the caliph did not made part directly in the burūz (military parade), he would preside it over the Bāb al-Sudda of Cordoba with his heir apparent, such as when his general Ghālib left Cordoba in military campaign. When Ghālib b. 'Abd al-Raḥmān received the Eastern title of Dhu al-Sayfayn (the holder of the two swords), he was granted a private audience with the Caliph al-Ḥakam II, the heir apparent, and the wazir șāhib al-madina at the qașr of Cordoba ${ }^{46}$. Two days later, on April 24, 975, on the occasion of his departure in campaign to Gormaz, he arranged that his burūz would pass by the qașr of Cordoba, where the caliph and the heir apparent, Hishām, showed themselves from the sath (rooftop) over Bāb al-Sudda, both raising their hands to God, asking for the assistance to the Muslim army, while the general displayed his armour and the two swords given by the caliph, which were hanging from each side ${ }^{47}$.

But the caliphal appearances at the Sudda of Cordoba were not only for the occasion of military parades when the army left in campaign. He is accounted to have attended a tournament over the Sudda, together with the future Hishām $\mathrm{II}^{48}$. He is said to have presided the alms distribution over the Sudda of Cordoba, also with his heir ${ }^{49}$. Although the Umayyad Caliphate of Cordoba did not organize processions for the occasion of religious festivities, or at least we do not have such accounts, as in the case of the Fatimid Caliphate in Cairo, it was the moving of the caliph from the mosque to the majlis of the palace-city which started the motion of the caliphal reception for the "İd al-Aḍhā or the 'İd al-Fițr, as pointed out by the foundational study of Barceló on the receptions organized on the occasion of such religious festivities ${ }^{50}$. The processions between Cordoba and Madīnat al-Zahrā' were mostly military processions or parades, either for the reception of ambassadors ${ }^{51}$ and tributaries or for the occasion of the leaving of the army in military campaigns, as pointed out above.

While considered as a non-processional ceremonial, as in the Fatimid case, where the caliph was the central piece of the procession, nevertheless the Andalusi ceremonial had also an important processional stance in the ritual life of Cordoba and Madinat alZahrā'. The importance of the processional ceremonial in al-Andalus, between the duo Cordoba and Madinat al-Zahrā', is perhaps best epitomized in the aforementioned leaving of Ghālib, in 975 , in a military campaign to respond to the Christian attack to the fortress of Gormaz. He left Madinat al-Zahrā' crossing the road in military parade until reaching the city gates of Cordoba, where the caliph presided over the Sudda with his heir. public ceremonial would coexist in the same occasions. That is the case of the ruküb of 
975, in which al-Hakam II was part of a procession led by his young son and heir, attended in pomp and protocol by his courtiers. Such scene not only underlines the development of the processional ceremonial under his rule, but also the dual aspect of the Umayyad ritualization: it was a processional ceremony with a courtly setting, directed both to the ahl al-qașr and the common caliphal subject. It furthermore exposed to a broader audience - of high and low rank - the courtly setting of the ahl alqașr in a complete submission towards the caliph, performing the prostration and kissing the feet before the ruler and his heir ${ }^{52}$, a gesture - the proskynesis - which was thought of not having taken place in the ceremonies in the Umayyad al-Andalus ${ }^{53}$.

That the public appearances of the caliph or the military burūz were not audience scenes does not mean that they were no less ceremonial settings. Far from being more relaxed settings, the performance of the public ritual was duly prepared and organized, no less than the majlis scenes. Being street scenes rather meant that they were accessible to a much broader audience, of both high and low rank. This was also true for the ritualized scenes played at public executions. The public executions and crucifixions had the Bāb al-Sudda as setting. The ritualization of some of these executions was carefully planned and was part of the ceremonial liturgy of blood, as pointed out before. The execution of the traitors of Simancas is perhaps the best example of a public blood ceremony presided by the caliph, having as a ritual setting the symbolic Bāb al-Sudda of Cordoba, emphasizing the power of the ruler and his justice, which is carefully articulated in the caliph's speech to the population. $\mathrm{He}$ addressed directly his crucified officials, before they were lanced, as well as his subjects, stressing the justice and service of the caliph towards his people. Despite being true that the sources must be read according to their political and courtly support, they also account how the population gathered around the platform purposely raised for this occasion, right next to the Sudda. The caliph was surely aware of certain limitations of his address - if he would be heard by all of those gathered there nevertheless he was even more aware of his volatile legitimacy, in a moment of a disastrous defeat for his army and dynasty. The address to the population was not a rare situation for Muslim dynasties. In fact, the khuța (preaching) of the Friday prayer was used for the purpose of addressing a broader population, usually in much larger spaces, such as the mosque of Cordoba. Thus, the caliph intended not only to address an elite audience - the high officials of his army - but also a broader audience, to whom he was not only justifying his actions towards a loyal population, but also an exemplary act of justice, that such treason could not be tolerated.

As pointed out before, the existence of a liturgy of blood as a ceremonial typology or setting is particularly well testified in the occasion of the capital punishment of one hundred Christian prisoners, whose executions were presided by the caliph sat on the upper majlis of his munya, seen by his subjects, while Ibn Ḥayyān accounts that the scene consisted of a reception, a ceremony, as it was the first julūs of the caliph at the munya.

According to Oleg Grabar, the ceremonial "was used to organize the life of an evergrowing court and the complex government of the empire". But it was not only functional; it was also a set of rules and attitudes for what has been called "the conduct of majesty" ${ }^{54}$. And thus, while the liturgy of blood had a practical purpose of justice and administration, that of punishing the caliphal traitors, it was nevertheless conducted in the utmost set of rules and attitudes, to exalt the majesty of the caliph. "The conduct of 
majesty," completed through the ceremonial as a setting of rules of government, was achieved through the performance of a ceremonial language understood by those involved in the theatralization of power, by the resort to a widespread symbology. Such performance reveals the importance of the comparative perspective, which will be further developed in a future research, from the point of view of the concepts and the ritualization of power.

\section{NOTES}

1. BARCELÓ, Miquel - "El Califa Patente: el ceremonial omeya de Córdoba o la escenificación del poder". in El sol que salió por Occidente. Estudios sobre el Estado omeya en al-Andalus. Valencia: Universitat de València, 2010, pp. 151-169, 153-154.

2. The book published only in 1969, under the title Die höfische Gesellschaft ("The court society"), had been originally submitted in 1933 as Elias' habilitation thesis at Heidelberg, but was never accepted due to its author's Jewish heritage. ELIAS, Norbert Die höfische Gesellschaft. Frankfurt am Main: Suhrkamp, 1969; ELIAS, Norbert - The court society. Trans. Edmund Jephcott. New York: Pantheon Books, 1983. See also EL CHEIKH, Nadia Maria - "Court and courtiers. A preliminary investigation of "Abbasid terminology". in FUESS, Albrecht; HARTUNG, Jan-Peter (Ed.) - Court Cultures in the Muslim World. Seventh to nineteenth centuries. New York: Routledge, 2011, pp. 80-90.

3. FUESS, Albrecht and HARTUNG, Jan-Peter - "Introduction". in FUESS, Albrecht; HARTUNG, Jan-Peter (Ed.) - Court Cultures in the Muslim World. Seventh to nineteenth centuries. New York: Routledge, 2011, p. 2.

4. EL CHEIKH, Nadia Maria - "Court and courtiers. A preliminary investigation of "Abbasid terminology", ... p. 80.

5. EL CHEIKH, Nadia Maria - "Court and courtiers. A preliminary investigation of 'Abbasid terminology", ... p. 80.

6. I am currently developing this line of research in a comparative postdoctoral research, titled "Contested Ceremonies in al-Andalus: Religion and Imperial Ritual between Late Antiquity and Early Islam" at the RomanIslam - Center for Comparative Empire and Transcultural Studies (Universität Hamburg), funded by the Deutsche Forschungsgemeinschaft (German Research Foundation, DFG).

7. CONSTANTINE VII PORPHYROGENNETOS - De Ceremoniis. The Book of Ceremonies. Ed. and trans. Ann Moffat and Maxeme Tall. Vols. 1 and 2. Canberra: Australian Association for Byzantine Studies, 2012; HILĀL AL-ȘĀBĪ' - Rusūm Dār al-Khiläfa. The Etiquette, Protocol and Diplomacy of the 'Abbāsid Caliphate in Baghdād. Ed. Mīkhā'îl 'Awād. Baghdad: al-‘̄̄nī Press, 1964; HILĀL AL-Ṣ̄Ā̄i' Rusūm Dār al-Khiläfa. The Rules and Regulations of the 'Abbasid Court. Trans. Elie A. Salem. Beirut: American University of Beirut, 1977. Will be cited as HILĀL AL-ȘĀBĪ' - Rusūm Dār al-Khiläfa trans.; QĀḌi AL-NU'MĀN - Kitāb al-himma fĩ ădāb atbă'al-a'imma. Ed. Muḥammad Kāmil Ḥusayn. Cairo: Dār al-Fikr al-'Arabī, 1948.

8. IBN ḤAYYĀN - Al-Muqtabas li-Ibn Ḥayyān al-Qurțubī (al-juz' al-khāmis). Al-Muqtabas (V). Ed. Pedro Chalmeta, Federico Corriente and Mahmūd Șubḥ. Madrid/Rabat: Instituto Hispano Árabe de 
Cultura, Faculté des Lettres, 1979. Will be cited as MQ-V; IBN ḤAYYĀN - Crónica del Califa 'Abdarraman III an-Nasir entre los años 912 y 942 (al-Muqtabis V). Trans. Maria Jesús Viguera and Federico Corriente. Zaragoza: Anubar Ediciones, Instituto Hispano-Arabe de Cultura, 1981). Will be cited as MQ-V trans.; IBN HAYYĀN - Al-Muqtabis fl̆ akhbār balad al-Andalus. Ed. 'Abd al-Rahmān 'Alī al-Ḥajjī. Beirut: Dār al-Thaqāfa, 1965. Will be cited as MQ-VII; IBN ḤAYYĀN - Anales Palatinos del Califa de Córdoba al-Hakam II, por 'Isa Ibn Ahmad al-Razi. Trans. Emílio García Gómez. Madrid: Sociedad de Estudios y Publicaciones, 1967. Will be cited as MQ-VII trans.

9. MQ-V, 17; MQ-V trans., 23.

10. MQ-VII, 163; MQ-VII trans., 203.

11. VALLEJO, Antonio - "El Heredero Designado y el Califa. El Occidente y el Oriente en Madīnat al-Zahrā"”. Mainake XXXVI (2016), pp. 433-464, p. 445.

12. For example, when referring to the concealment of the third caliph, Hishām II, by the chamberlain al-Mansūr, al-Maqqarī uses the title imām. AL-MAQQARĪ - Nafh al-țîb min ghuṣn alAndalus al-rațīb wa dhikr wazìri-hā Lisān al-Dīn b al-Khațîb. Ed. R. Dozy, G. Dugat, L. Krehl and W.Wright. Vol. I. Leiden: Brill, 1855, vol 1, p. 264. Will be cited as AL-MAQQARĪ, Nafh al-țîb. Maribel Fierro has already pointed out the use of the title by the Umayyads of Cordoba. See FIERRO, Maribel - "Sobre la adopción del título califal por “Abd al-Raḥmān III". Sharq Al-Andalus: Estudios mudéjares y moriscos 6 (1989), pp. 33-42, p. 33.

13. In a panegyric, the caliph al-Hakam II is called "mahdī of the Banū Marwān". See MQ-VII, p. 56; MQ-VII trans., p. 73.

14. For example, in a letter sent by two family members of the Banū Idrīs, Ibrāhīm and Abū al-'Aysh recognize the Umayyad right to the caliphate - ma'rifat ${ }^{a n}$ bi-l-haqq amir al-mu'minin acknowledging their heritage to the imamate - āthār imāmati-hi. See MQ-V, p. 375; MQ-V trans., p. 281.

15. Both 'Abd al-Raḥmān III and al-Ḥakam II were commonly referred in sources as al-khalifa. MQVII, p. 50; MQ-VII trans., p. 68; MQ.VII, p. 58; MQ-VII trans., p. 76.

16. The discussion of the meaning of the title khalifa has been the focus of several studies, especially concerning its meaning and use in the aftermath of the death of the Prophet Muhammad. The most famous of these studies is the one authored by Patricia Crone and Martin Hinds, in which is demonstrated that the title was originally khalifat Allāh and not khalifat rasūl Allāh, as latter tradition stances, and it was used to underline the Umayyad caliphs as both religious and political authorities. Such religious authority would then collapse and became dispersed in the hands of several 'ulamā and, at the same time, the inferring of khalifat rasūl Allāh as the original caliphal title was developed under a historical framework which saw the Umayyads as corrupt and unorthodox caliphs. Please see: CRONE, Patricia and HINDS, Martin God's caliph: religious authority in the first centuries of Islam. London: Cambridge University Press, 1986.

17. MQ-V, p. 10; MQ-V trans., p. 16.

18. MANZANO, Eduardo - La corte del califa. Cuatro años en la Córdoba de los omeyas. Barcelona: Crítica, 2019, p. 93.

19. MQ-V, p. 435; MQ-V trans., pp. 325-326.

20. MQ-V, p. 406; MQ-V trans., p. 303.

21. MQ-V, p. 423; MQ-V trans., p. 316.

22. MQ-V, p. 445; MQ-V trans., p. 333.

23. TORRES BALBÁS, Leopoldo - "Bāb al-Sudda y las Zudas de la España Oriental”. Crónica Arqueológica de la España Musulmana XXX 2 (1952), pp. 165-175, p. 72.

24. HERRERO, Omayra - El perdón del gobernante (al-Andalus, ss. II/VIII-V/XI). Una aproximación a los valores político-religiosos de una sociedad islámica pre-moderna. Salamanca: University of Salamanca, 2012. Ph.D. thesis, pp. 542-555. HERRERO, Omayra 
- El perdón del gobernante (al-Andalus, ss. II-V/VIII-XI). Helsinki: Academia Scientiarum Fennica, 2016.

25. CHALMETA, Pedro - "La 'sumisión de Zaragoza' del 325-937". Anuario de historia del derecho español 46 (1976), pp. 503-526, p. 517, see note 75.

26. LÉVI-PROVENÇAL, Évariste - "España Musulmana, hasta la caída del califato de Córdoba (711-1031 J.C.)”. in MENÉNDEZ PIDAL, Ramón (Ed.) - Historia de España. Vol. IV. Madrid: EspasaCalpe, 1982, pp. 332-333.

27. HILĀL AL-ȘĀBĪ' - Rusūm Dār al-Khilāfa trans., pp. 16-18.

28. MISKAWAYH - Tajārib al-Umām. The experience of the nations. Ed. H.F. Amedroz. Vol. I, Reigns of Muqtadir, Qahir and Radi. London: Oxford, 1920, pp. 53-56.

29. EL CHEIKH, Nadia Maria - "The institutionalization of the "Abbasid ceremonial". in HUDSON, John; RODRIGUEZ, Ana (Eds.) - Diverging paths?: the shapes of power and institutions in medieval Christendom and Islam. Leiden: Brill, 2014, pp. 351-370, p. 360; CARDOSO, Elsa - "The scenography of power in al-Andalus and the "Abbasid and Byzantine ceremonials: Christian ambassadorial receptions in the court of Cordoba in a comparative perspective". Medieval Encounters. Jewish, Christian and Muslim Culture in Confluence and Dialogue (January 2018), pp. 1-45, pp. 17-19.

30. GEERTZ, Clifford - Negara: the theatre state in nineteenth-century Bali. Princeton: Princeton University Press, 1980, p. 109.

31. AL-T TABARĪ - The History of al-Ṭabarī, vol. XXXI, The War between Brothers. Trans. Michael Fishbein. Albany: Sate University of New York Press, 1992, p. 3.

32. GRABAR, Oleg - Ceremonial and Art at the Umayyad Court. New Jersey: Princeton University, 1955. Ph.D. thesis, p. 155.

33. IBN H̦AYYĀN - Al-Sifr al-Thānī min Kitāb al-Muqtabas li-Ibn Hayyān al-Qurțubī. Ed. Maḥmūd 'Alī al-Makkī. Riyad: Markaz al-Malik Fayṣal li-l- Buhūth wa al-Dirāsāt al-Islāmiyya, 2003, p. 185; IBN HAYYĀN - Crónica de los emires al-Hakam I y 'Abd ar-Rahman II entre los años 796 y 847 [al-Muqtabis II-1]. Trans. Mahmud 'Ali Makki, Federico Corriente. Zaragoza: Instituto de Estudios Islámicos y del Oriente Próximo, 2001, p. 91; MQ-VII, p. 103; MQ-VII trans., p. 132.

34. IBN HAZM - El Collar de la Paloma. Tratado sobre el Amor y los Amantes. Trans. Emilio García Gómez. Madrid: Sociedad de Estudios y Publicaciones, p. 1967.

296-297; MQ-V, p. 334; MQ-V trans., p. 251.

35. On September 9, 973, al-Hakam II welcomed both Muslim and Christian ambassadors, who were carrying messages to "his door" - ilā Bābi-hi. MQ-VII, 138; MQ-VII trans., 173.

36. MQ-V, 474; MQ-V trans., 355.

37. MQ-VII, p. 186; MQ-VII trans., p. 225.

38. AL-MAQQARI - Nafh al-țib, p. 250; AL-MAQQARĪ - The History of the Mohammedan Dynasties in Spain. Naf̣̣ al-țīb min ghoṣn al-Andalus al-Rațīb wa Ta'rīkh Lisān al-Dīn Ibn al-Khațīb. Trans. Pascual de Gayangos. Vol. II. London: Oriental Translation Fund, 1843, p. 174. Will be cited as AL-MAQQARĪ Nafh al-țib trans.

39. About the bay'a in al-Andalus and in the Islamic West, see: PELÁEZ, Alejandro - "¿Qué es la bay'a? Definición y usos del juramento de lealtad en el occidente islámico (ss. viii-xv)". Hesperia culturas del Mediterráneo (March 2020), pp. 233-247; PELÁEZ, Alejandro - "Reconocimiento y transmisión de la autoridad política en el Occidente islámico (ss. viii-xv): la bay‘a en la dinámica imperial”. in DEJUGNAT, Yann (Ed.) - Écritures du pouvoir. Ausonius Éditions, (forthcoming).

40. Una crónica anónima de al-Nasir. Trans. Évariste Lévi-Provençal and Emilio García Gómez. Madrid/Granada: Consejo Superior de Investigaciones Científicas/ Instituto Miguel Asín, 1950, p. 91.

41. AL-MAQQARĪ - Nafh al-țïb, p. 250; AL-MAQQARĪ - Nafh al-țiib trans., p. 156.

42. CONSTANTINE VII PORPHYROGENNETOS - De Ceremoniis...., Vol. I, pp. 192-193. 
43. For the Fatimid ritual and ceremonial see the foundational work of Paula Sanders. SANDERS, Paula - The Court ceremonial of the Fatimid Caliphate in Egypt. New Jersey: Princeton University, 1984. Ph.D. thesis. The thesis was edited and published afterwards: SANDERS, Paula - Ritual, politics, and the city in Fatimid Cairo. Albany: State University of New York Press, 1994.

44. MQ-V, pp. 445-446; MQ-V trans., pp. 334-335.

45. MQ-V, pp. 431-432; MQ-V trans., pp. 322-323.

46. MQ-VII, pp. 219-221; MQ-VII trans., pp. 259-261.

47. MQ-VII, p. 221; MQ-VII trans., p. 261. See also: ALBARRÁN, Javier - Ejércitos benditos. Yihad y memoria en al-Andalus (siglos X-XIII). Granada: Editorial Universidad de Granada, 2020, p. 70, p. 126; ALBARRÁN, Javier; CARDOSO, Elsa - "De puertas, banderas y súplicas a Dios: ceremonial y guerra santa en al-Andalus (s. X)". Intus-Legere. Historia (forthcoming, 2021).

48. On April 21, 975, al-Ḥakam II went to the sațh over Bäb al-Sudda, together with the prince Hishām, whom he was willing to amuse with the military drills. MQ-VII, p. 223; MQ-VII trans., p. 264.

49. On the June 15, 975, the caliph made again a public appearance over the Sudda of the palace of Cordoba, together with Hishām, this time not for the sake of a military ceremony, but rather for an act of Muslim piety, as they were presiding from there the caliphal distribution of alms. MQVII, p. 233; MQ-VII trans., pp. 275-276.

50. BARCELÓ, Miquel - "El Califa Patente: el ceremonial omeya de Córdoba o la escenificación del poder" ..., p. 159.

51. I have discussed elsewhere the diplomatic ceremonial around the unattainable figure of the caliph. See: CARDOSO, Elsa - "The scenography of power in al-Andalus (...)", ...; CARDOSO, Elsa Diplomacy and oriental influence in the court of Cordoba ( $9^{\text {th }}-10^{\text {th }}$ centuries). Lisbon: University of Lisbon, 2015. M.A. thesis. See, for example, the description of the diplomatic reception of John of Gorze, ambassador of Otto I. See JUAN, ABAD DE SAN ARNULFO - "La embajada del emperador de Alemania Otón I al califa de Córdoba Abderrahmán III. Vida de San Juan de Gortz" (Trans. Paz y Melia). Boletín de la Academia de Ciencias, Bellas Letras y Nobles Artes de Córdoba 33 (1931); JEAN DE SAINT-ARNOUL - La vie de Jean, Abbé de Gorze. Trans. Michel Parisse. Paris: Picard, 1999.

52. MQ-VII, pp. 212-215; MQ-VII trans., pp. 252-255.

53. FIERRO, Maribel - "Pompa y Ceremonia en los Califatos de Occidente Islámico (s. II/VIII-IX/ XV)" Cuadernos del CEMyR 17 (2009), pp. 125-152, p. 137.

54. GRABAR, Oleg - Ceremonial and Art at the Umayyad Court ..., p. 51.

\section{AUTHOR}

\section{ELSA CARDOSO}

Universität Hamburg, RomanIslam - Center for Comparative Empire and Transcultural Studies, 20146 Hamburg, Germany. elsa.fc@gmail.com. https://orcid.org/0000-0003-3319-3745 